\title{
Article \\ Nanotubular Oxide Layer Formed on Helix Surfaces of Dental Screw Implants
}

\author{
Magdalena Jażdżewska *(D) and Michał Bartmański \\ Faculty of Mechanical Engineering and Ship Technology, Gdańsk University of Technology, Narutowicza 11/12, \\ 80-233 Gdańsk, Poland; michal.bartmanski@pg.edu.pl \\ * Correspondence: magdalena.jazdzewska@pg.edu.pl; Tel.: +48-58-347-17-96
}

\section{check for} updates

Citation: Jażdżewska, M.; Bartmański, M. Nanotubular Oxide Layer Formed on Helix Surfaces of Dental Screw Implants. Coatings 2021, 11, 115. https://doi.org/10.3390/ coatings11020115

Received: 11 December 2020

Accepted: 18 January 2021

Published: 20 January 2021

Publisher's Note: MDPI stays neutral with regard to jurisdictional claims in published maps and institutional affiliations.

Copyright: (c) 2021 by the authors. Licensee MDPI, Basel, Switzerland. This article is an open access article distributed under the terms and conditions of the Creative Commons Attribution (CC BY) license (https:// creativecommons.org/licenses/by/ $4.0 /)$.

\begin{abstract}
Surface modification is used to extend the life of implants. To increase the corrosion resistance and improve the biocompatibility of metal implant materials, oxidation of the Ti- $13 \mathrm{Nb}$ 13Zr titanium alloy was used. The samples used for the research had the shape of a helix with a metric thread, with their geometry imitating a dental implant. The oxide layer was produced by a standard electrochemical method in an environment of $1 \mathrm{M} \mathrm{H}_{3} \mathrm{PO}_{4}+0.3 \% \mathrm{HF}$ for $20 \mathrm{~min}$, at a constant voltage of $30 \mathrm{~V}$. The oxidized samples were analyzed with a scanning electron microscope. Nanotubular oxide layers with internal diameters of 30-80 nm were found. An analysis of the surface topography was performed using an optical microscope, and the Sa parameter was determined for the top of the helix and for the bottom, where a significant difference in value was observed. The presence of the modification layer, visible at the bottom of the helix, was confirmed by analyzing the sample cross-sections using computed tomography. Corrosion tests performed in the artificial saliva solution demonstrated higher corrosion current and less noble corrosion potential due to incomplete surface coverage and pitting. Necessary improved oxidation parameters will be applied in future work.
\end{abstract}

Keywords: nanotubular oxide; helix surfaces; dental implants; roughness; corrosion properties

\section{Introduction}

Titanium and its alloys are nowadays among the most popular biomaterials, called the "gold standard" for endosseous dental implants, even if some adverse reactions may be expected. They possess a lot of important properties, such as their low density, suitable fatigue strength, Young's modulus and specific tensile strength, high resistance to brittle cracking, high corrosion resistance, and the best biocompatibility. Despite that, titanium and its alloys need surface modifications for early osseointegration [1,2]. The type of commercial implant determines surface topography and differences in geometry [3].

Surface modification is nowadays an obligatory treatment of dental implants. Bioactivity of the surface resulting in adhesion of osteoblasts and bone ingrowth can be achieved by the development of surface roughness, creation of bioactive films, and deposition of coatings [2]. Many different methods have been used to change the surface roughness of dental implants, including mechanical techniques such as grinding, polishing, machining, sandblasting and attrition, chemical etching in acids, alkali and fluorides, electrophoretic deposition, and laser treatments [4-11].

The interaction of cells and adsorption of proteins depends on surface structure and is significant in the presence of nanometric pores, which increase the rate of osseointegration and biomechanical fixation [2,7,8,12-17]. A significantly higher bone contact of $27 \%$ $(p<0.05)$ was observed in nanotextured compared to machined implants [18]. However, reproducibility of nanoscale surface profiles of titanium with chemical modifications such as acid-etching is quite difficult to achieve and unreliable, and knowledge on the ideal surface roughness parameters for rapid osseointegration is still lacking $[19,20]$. 
Among various surface treatments, artificial oxidation seems particularly plausible for titanium dental implants resulting in high corrosion resistance and biocompatibility [21]. The oxidation required for dental implants is currently mostly applied by micro-arc oxidation (MAO) [22,23] and electrochemical oxidation [24]. Gaseous oxidation has also been proposed [25]. MAO induced titanium oxide formation in the anatase crystalline phase and also incorporated $\mathrm{Ca}, \mathrm{P}$, and $\mathrm{Mg}$ in the film [26-33]. An oxide thickness of 600-1000 nm demonstrated significantly stronger bone responses than that of 17 or $200 \mathrm{~nm}$ [30]. The coatings comprising nano $\mathrm{TiO}_{2}$ and nanohydroxyapatite (nanoHAp) demonstrated a torque value of coated screws significantly greater than that of nanoHAp covered screws [34].

The creation of nanotubular oxide layers on titanium and its alloys is well-known. The formation of nanotubular oxide structures on dental implants has not often been investigated and developed. The overly short life of dental implants observed proves the ineffectiveness of the applied surface modifications and provides prompts for further research. The anodization depends to a great extent on the geometry and structure of the surfaces involved. Indeed, the formation of titanium dioxide nanotubes on flat titanium surfaces, provided by well-known suppliers, does not have the same effect on titanium implants, mainly due to the geometry of the implant, which changes the priority, intensity, and interconnection of the electrochemical processes [35]. Nanotubular oxide layers have been reported to increase the bioactivity of titanium implants [36-38], the nucleation and growth of hydroxyapatite coatings [39], and to introduce antibacterial effects after loading the nanotubes with drugs $[40,41]$. Such a type of surface was already fabricated on the nontoxic Ti-13Zr- $13 \mathrm{Nb}$ alloy investigated here [42,43]. This research was aimed at an assessment of the creation of nanotubular oxide layers on screw fixed dental implants and the characterization of the layers obtained on the tops and bottoms of helices of implants.

\section{Materials and Methods}

\subsection{Material}

The biphase $\alpha+\beta$ Ti-13Zr-13Nb alloy (SeaBird Metal Materials Co., Baoji, China) with chemical composition presented in Table 1 was investigated in the as-received state.

Table 1. The chemical composition of the Ti-13Zr-13Nb alloy, wt.\%. (based on the manufacturer's certificate).

\begin{tabular}{ccccccc}
\hline Element & $\mathbf{Z r}$ & $\mathbf{N b}$ & $\mathbf{O}$ & $\mathbf{C}$ & $\mathbf{N}$ & $\mathbf{T i}$ \\
\hline wt. $\%$ & 13.0 & 13.0 & 0.11 & 0.04 & 0.019 & remainder \\
\hline
\end{tabular}

\subsection{Preparation of Specimens}

Round specimens of height $9 \mathrm{~mm}$ and diameter $8 \mathrm{~mm}$ were prepared by precision milling. The metric thread was cut on all specimens. The remaining impurities were cleaned and the surface was prepared by sand blasting with corundum for $15 \mathrm{~s}$. The cleaning was performed at Aesculap Chifa Ltd. in Nowy Tomysl, Poland. Immediately before oxidation, the specimens were washed in an ultrasonic bath (Sonic 3, Polsonic, Warsaw, Poland) in isopropanol (POCH, 99.8\%, Gliwice, Poland) for $10 \mathrm{~min}$, in distilled water for $3 \mathrm{~min}$, and methanol (POCH, 99.8\%, Gliwice, Poland) for $10 \mathrm{~min}$.

\subsection{Electrochemical Oxidation}

The oxidation was performed using a direct current power supply (MCM/SPN11001C, Shanghai MCP Corp., Shanghai, China). The specimen tested was connected to the power supply as an anode and the Pt electrode was used as a cathode. The electrolytic bath contained a solution of $150 \mathrm{~mL}$ of distilled water, $20 \mathrm{~mL}$ of $1 \mathrm{M} \mathrm{H}_{3} \mathrm{PO}_{4}$, and $1.5 \mathrm{~mL}$ of $0.3 \%$ HF (both from POCH, Gliwice, Poland). The distance between the electrode tested and the Pt electrode was $15 \mathrm{~mm}$. The solution was neither aerated nor deaerated, and nonstirred. The experiments were carried out at ambient temperature. The experiments were performed at a voltage of $20 \mathrm{v}$ for $30 \mathrm{~min}$ based on previously conducted experiments [42]. 


\subsection{SEM Surface Examination}

Scanning electron microscopy (SEM JEOL JSM-7800 F, JEOL Ltd., Tokyo, Japan) instrument equipped with EDS chemical analyzer (Edax Inc., Mahwah, NJ, USA).

\subsection{Light Microscopy Assessment of Roughness}

A light microscope (VHX-7000, Keyence, Osaka, Japan) was applied to examine the surface topography. Roughness parameters determined by the 3D Form Measurement software were applied to the Sa area.

\subsection{Computer Tomography}

Tomographic images were obtained using Phoenix v/Tome/xs computer tomography (General Electric, Lewistown, PA, USA).

\subsection{Corrosion Examinations in Simulated Body Fluid}

Corrosion tests were performed by a potentiodynamic method in simulated body fluid (SBF) at a temperature of $38^{\circ} \mathrm{C}$. The electrochemical measurements were achieved by using a potentiostat/galvanostat (Atlas 0531, Atlas Sollich, Gdańsk, Poland). An artificial saliva solution (SBF) was prepared according to EN ISO 10993-15 [44] by dissolving reagent grade chemical $\left(\mathrm{NH}_{2}\right)_{2} \mathrm{CO}\left(0.13 \mathrm{gL}^{-1}\right), \mathrm{NaCl}\left(0.7 \mathrm{gL}^{-1}\right), \mathrm{NaHCO}_{3}\left(1.5 \mathrm{gL}^{-1}\right), \mathrm{Na}_{2} \mathrm{HPO}_{4}$ $\left(0.26 \mathrm{gL}^{-1}\right), \mathrm{K}_{2} \mathrm{HPO}_{4}\left(0.2 \mathrm{gL}^{-1}\right), \mathrm{KSCN}\left(0.33 \mathrm{gL}^{-1}\right), \mathrm{KCl}\left(1.2 \mathrm{gL}^{-1}\right)$ (POCH, Gliwice, Poland). The potential was measured vs. a saturated calomel electrode (SCE) located in the HaberLuggin capillary. As a counter electrode, a standard platinum electrode was used. The test specimen was stabilized in a solution of artificial saliva for $30 \mathrm{~min}$ at open circuit potential OCP. The potential change rate was $1 \mathrm{mV} / \mathrm{s}$ within a scan range of -2000 to $1000 \mathrm{mV}$. The solutions were agitated with a magnetic stirrer. Using the Tafel extrapolation method, the corrosion potential $\left(E_{\mathrm{corr}}\right)$ and corrosion current density $\left(i_{\mathrm{corr}}\right)$ values were determined.

\section{Results and Discussion}

\subsection{Substrate Specimens}

The surface of the non-oxidized alloy is shown in Figure 1 at two different magnifications. The relatively smooth surface and screw lines can be seen.
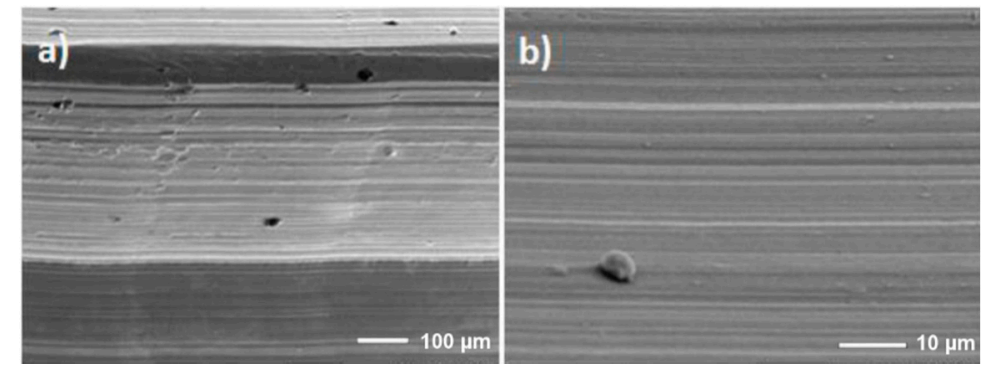

Figure 1. Surface of reference specimen at different magnification: (a) $130 \times$, (b) $1700 \times$.

\subsection{Oxidized Specimens}

Figure 2 shows the appearance of the nanotubular oxide layer only in the area at the bottom of the helix. The pores created are spherical and longitudinal. They possess a diameter ranging between 30 and $80 \mathrm{~nm}$. The layer is well adjacent to the substrate and it has a small number of cracks and surface defects. The gradual decrease of the nanoporous layer and its absence at the top of the helix may be attributed to different current densities, different electrochemical potential, and as a consequence a different course of chemical reactions. The current is screened at the bottom at a given potential and the resultant value is sufficient for electrochemical oxidation to occur. At the tops, the current density is too high and the nanotubes formed undergo fast oxidation, its rate exceeding that of chemical dissolution resulting in nanotubes. The current density is higher at the tops of such surfaces, 
with the effect attributed to the difficult transport of oxygen to and reaction products from this area, and stepwise depolarization of the area close to the bottom followed by a change in open circuit and corrosion potentials. These processes can shift the current and potential values beyond those necessary to form nanotubular oxide layers.
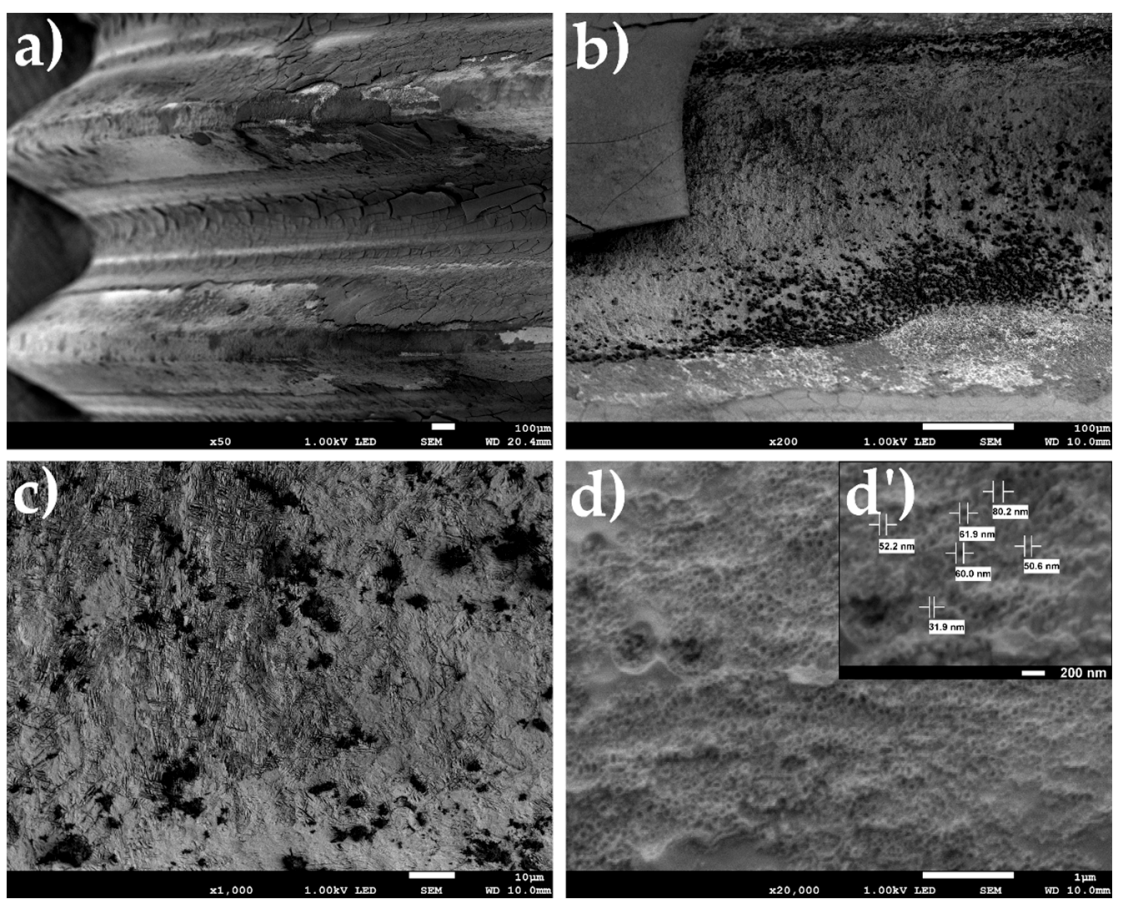

Figure 2. Surfaces of specimens oxidized in an electrochemical way: (a) view of specimen, (b) surface of helix top, (c) surface between top and bottom of the helix, (d) bottom of the helix (with different magnifications $-d^{\prime}$, with the result of measuring the diameter of nanotubes).

The EDS examination results presented in Table 2 suggest the obtaining of a layer of titanium oxide on the surface, which is confirmed mainly by the content of titanium and oxygen. High P content results from the absorption of $\mathrm{HPO}_{4}{ }^{2-}$ anion within the layer pores and it is desired for better bioactivity of the surface. Trace amounts of $\mathrm{Ca}, \mathrm{K}, \mathrm{Fe}$ are observed, which most likely were impurities in the distilled water used.

Table 2. The EDS examination results of the chemical composition of the oxide layer.

\begin{tabular}{ccc}
\hline Element & Wt. Pct. & At. Pct. \\
\hline $\mathrm{O}$ & 48.49 & 71.65 \\
\hline $\mathrm{Zr}$ & 5.72 & 2.07 \\
\hline $\mathrm{P}$ & 19.29 & 14.72 \\
\hline $\mathrm{Nb}$ & 6.91 & 1.76 \\
\hline $\mathrm{K}$ & 0.68 & 0.41 \\
\hline $\mathrm{Ca}$ & 0.84 & 0.49 \\
\hline $\mathrm{Ti}$ & 17.77 & 8.77 \\
\hline $\mathrm{Fe}$ & 0.30 & 0.13 \\
\hline
\end{tabular}

Results of topography tests are presented in Figure 3. The surface of the top oxide layer is rough and well developed. The roughness profile is $630 \mathrm{~nm}$, the Sa average value is $1.39 \pm 0.79 \mu \mathrm{m}$ on the tip of the helix, and $5.69 \pm 2.98 \mu \mathrm{m}$ on the bottom of the helix (Table 3). Such values in the nanometric range are also useful. The differentiation of the area comprising small nanotubes and rough pores is important. Surface modification led 
to smoothing the tip of the helix as a result of dissolving roughness peaks. The influence of roughness on oseointegration has been proven. In the case of long-term implants, a positive osteoblast response is required. With increasing roughness, the possibility of osteoblasts settling increases [45]. High roughness also carries the risk of biofilm formation [46]. The topography results confirmed the obtaining of a surface with a high surface roughness value. The lowest values were obtained for the oxidized sample.

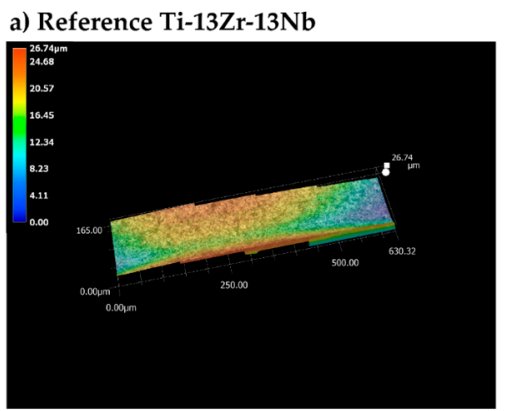

b) Ti-13Zr-13Nb (after sand blasting)

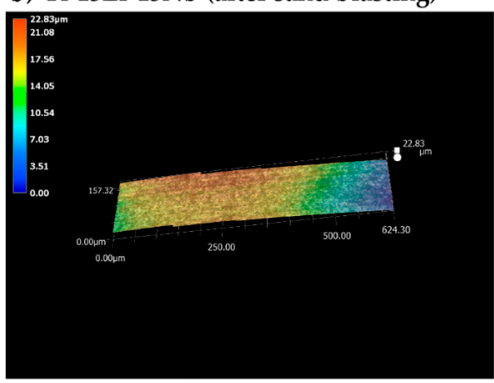

c) Oxidized Ti-13Zr-13Nb

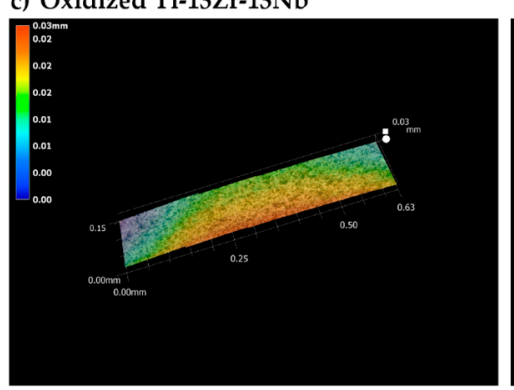

Figure 3. The topography of reference Ti-13Zr-13Nb before (a) and after (b) sand blasting and oxidized Ti-13Zr-13Nb surfaces (c) obtained by light microscopy; the bottom of the helix (left) and top (right).
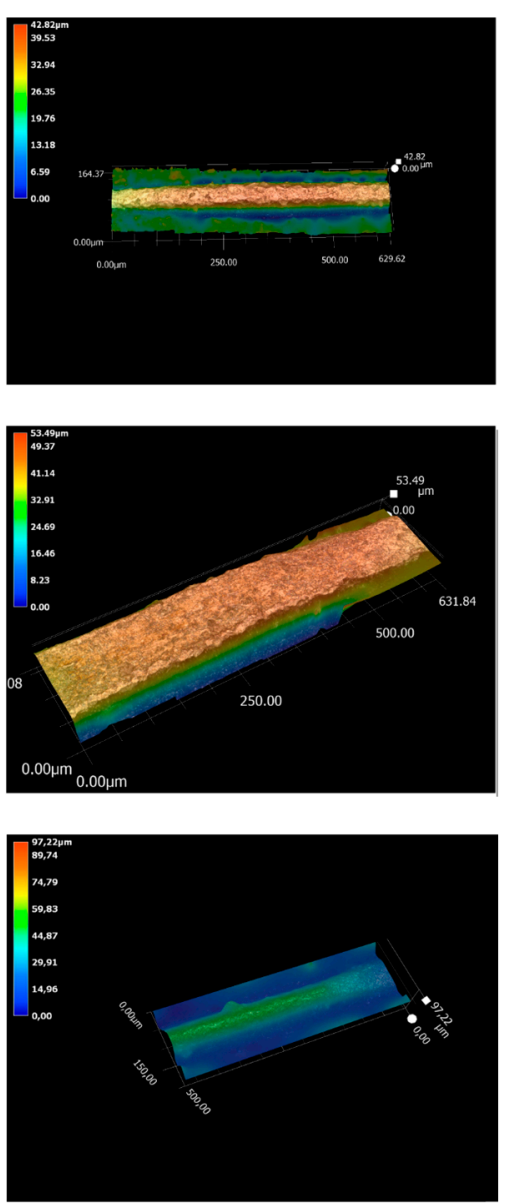

Table 3. Sa roughness parameters results.

\begin{tabular}{ccc}
\hline Specimen & \multicolumn{2}{c}{ Sa Parameters $(\mu \mathrm{m})$} \\
\cline { 2 - 3 } & Tip of the Helix & Bottom of the Helix \\
\hline Reference Ti-13Zr13Nb (before sand blasting) & $1.81 \pm 1.11$ & $9.10 \pm 4.62$ \\
Ti-13Zr-13Nb (after sand blasting) & $1.63 \pm 1.40$ & $9.94 \pm 5.51$ \\
Oxidized Ti-13Zr-13Nb & $1.39 \pm 0.79$ & $5.69 \pm 2.98$ \\
\hline
\end{tabular}

The CT investigations showed the appearance of modifications at the bottoms of the helix and not at the tops (Figure 4). The area of modification can be observed as grey and red areas at the bottoms and base alloy as white metal. 


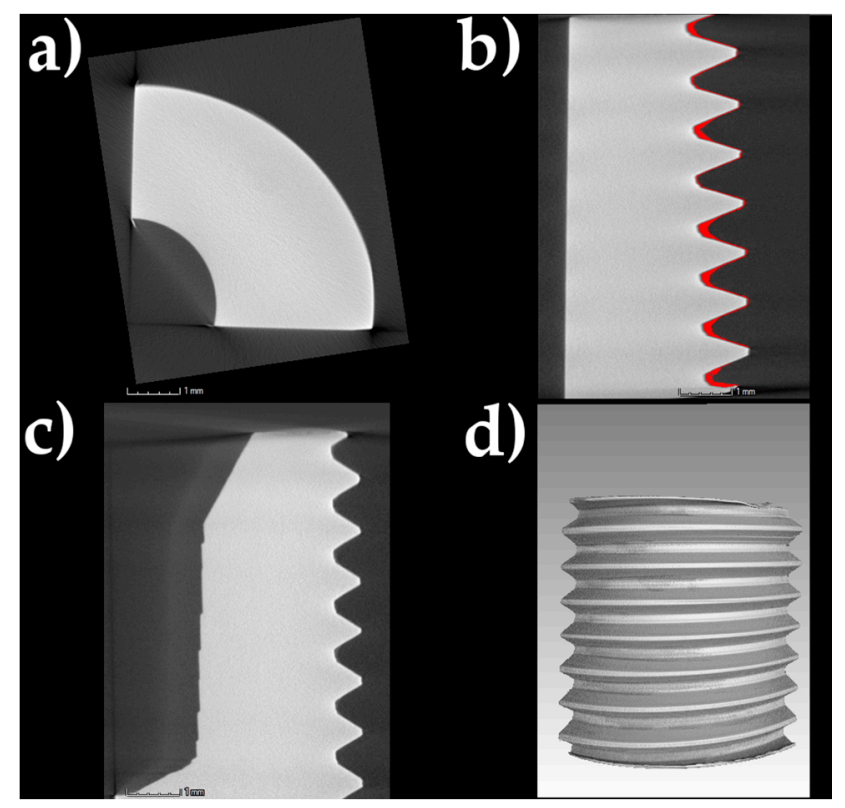

Figure 4. CT images: (a) horizontal cross-section with regard to y axis, $(\mathrm{b}, \mathrm{c})$ vertical cross-sections, (d) 3D sample model.

The corrosion results are presented in Figure 5 and Table 4 . The creation of the oxide layer became difficult because of much higher current values and a presumed shift of electrochemical potential into more anodic values resulting in the dissolution of metal rather than the oxidation of the surface. The local appearance of the nanotubular and highly rough surface is evidence that some microcells are formed due to change in potential. The local changes in $\mathrm{pH}$ value influence the anodization rate, the thickness of the oxide layer and its structure, or even its formation. In case of too low or too high acidity, the oxide layer is unable to achieve the nanotubular structure [47]. Here the anodization was made at the proper HF concentration enhancing the stabilization of the appropriate low $\mathrm{pH}$ value and resulting in a short oxidation time, thin nanotubes, a short distance between them, and scarce surface cracks. The roughness of the oxidized surface was close to that observed in similar experiments [48].

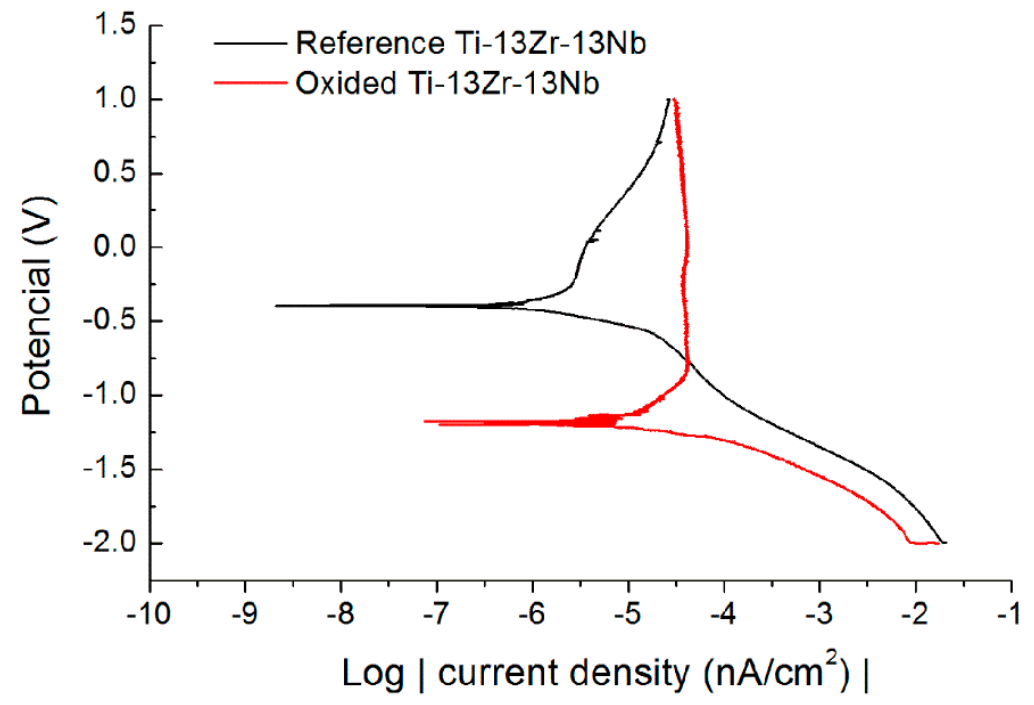

Figure 5. Potentiodynamic polarization curve of reference and oxidized Ti-13Zr-13Nb specimens. 
Table 4. Corrosion properties of reference and oxidized Ti-13Zr-13Nb specimens.

\begin{tabular}{ccc}
\hline Specimen & Current Density $\left(\mathbf{n A} / \mathbf{c m}^{2}\right)$ & Corrosion Potential $(\mathbf{m V})$ \\
\hline Reference Ti-13Zr-13Nb & 503.25 & -392.46 \\
\hline Oxidized Ti-13Zr-13Nb & 1451.00 & -1174.13 \\
\hline
\end{tabular}

The open-circuit potential (OCP) of the non-oxidized specimen was about $-199 \mathrm{mV} \mathrm{V}_{\text {(SCE) }}$. The anodic polarization exhibits a narrow plateau between 300 and $1150 \mathrm{mV}$, which can be attributed to the presence of natural titanium oxide on a specimen surface. The passive current value in this area ranged between 200 and $300 \mu \mathrm{A}$. For the previously oxidized specimen, the OCP was about $-616 \mathrm{mV}$. The anodic curve shows a very stable passive region between -200 and $2000 \mathrm{mV}$. The passive current was about $200 \mu \mathrm{A}$ in the entire region. However, despite high passive regions, the increase in corrosion current density after oxidation shows that the surface has not been uniformly covered with oxide layers and many microcells could appear in these oxidation conditions. The titanium dioxide layer formed on the surface of the titanium can provide increased corrosion resistance only if it is continuous over the entire surface of the alloy. The layer presented in the paper is characterized by cracks and a lack of continuity. This results in the formation of so-called "corrosion channels", which accelerate the degradation of the material. A similar effect was obtained in research [49]. The occurrence of this phenomenon may explain the deterioration of the corrosive properties compared to the reference sample.

The microscopic investigation reference specimens after corrosion tests showed effects of pitting, some discontinuity of material, and a heterogeneous structure at the bottoms of the helix and at the tops (Figure 6). The microscopic investigation specimens oxidized in an electrochemical way and showed a network of cracks in the surface of the helix top and corrosion pitting in the bottom of the helix (Figure 7), it is probably related to the grater thickness of the obtained modification, which was confirmed by CT tests-Figure $4 \mathrm{~b}$.
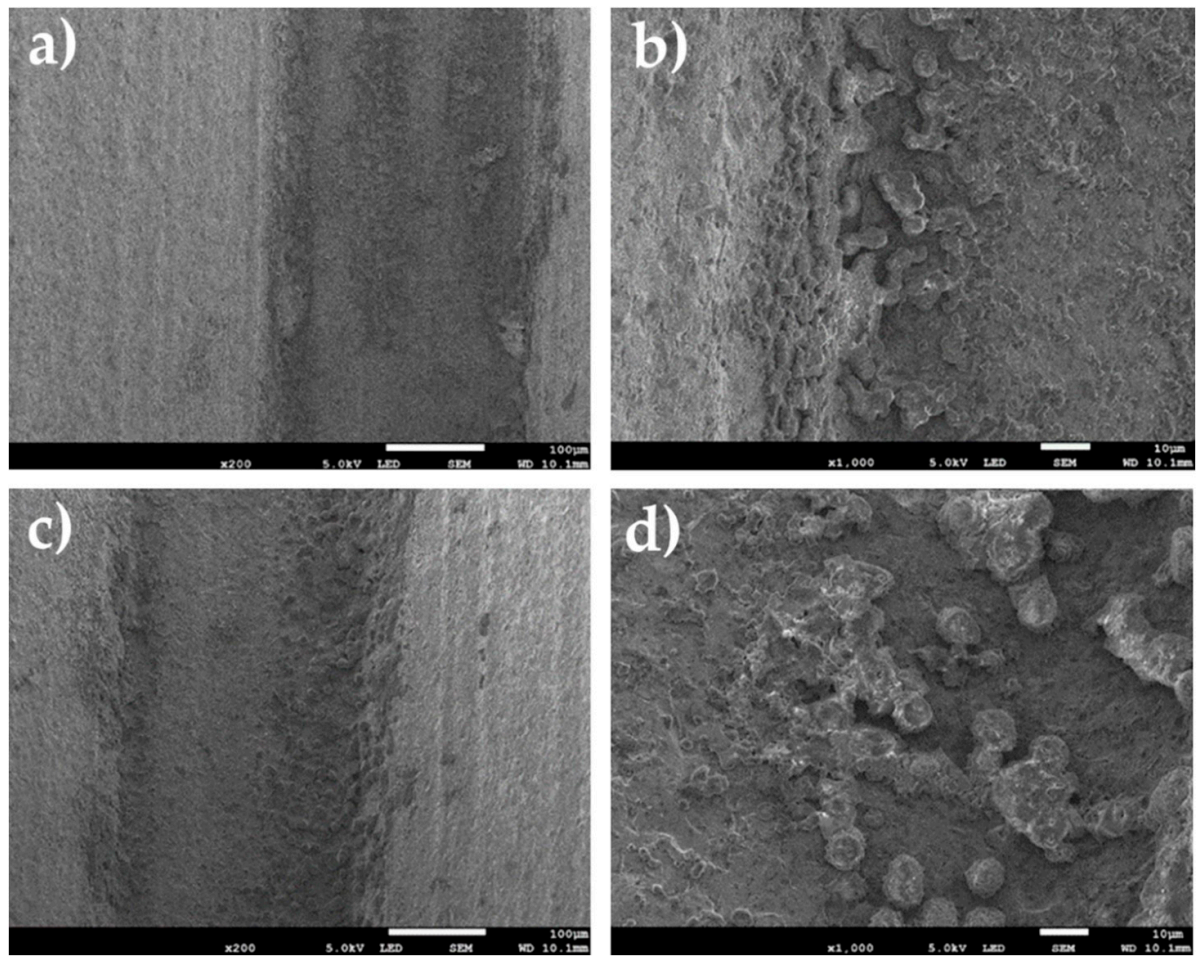

Figure 6. Surface of reference specimen after corrosion test at different magnifications: (a) surface of helix top $\times 200$, (b) surface of helix top $\times 1000$, (c) bottom of the helix $\times 200$, (d) bottom of the helix $\times 1000$. 

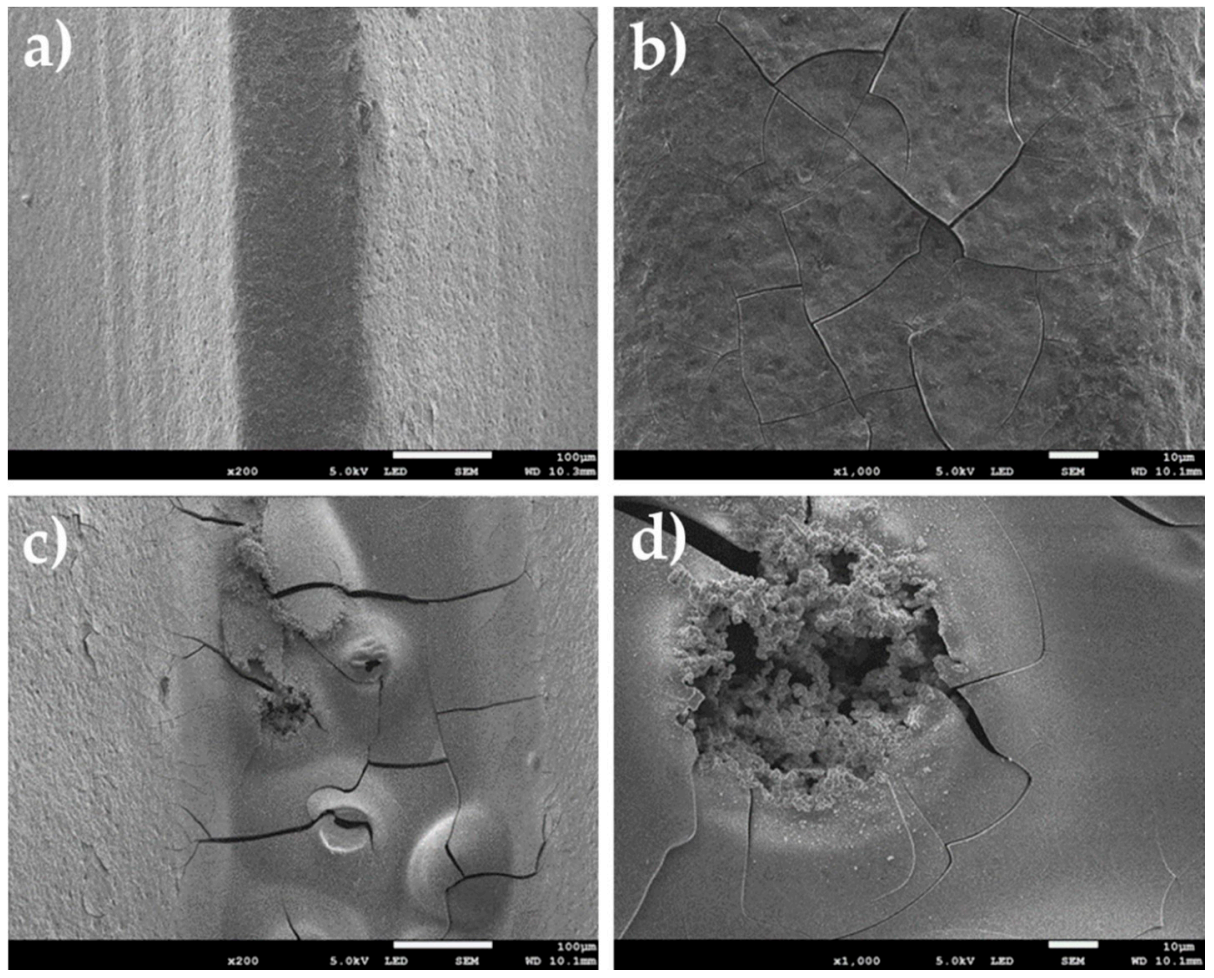

Figure 7. Surfaces of specimens oxidized in an electrochemical way after corrosion tests: (a) surface of helix top $\times 200$, (b) surface of helix top $\times 1000$, (c) bottom of the helix $\times 200$, (d) bottom of the helix $\times 1000$.

\section{Conclusions}

In summary, nanotubular oxidation on the helix lines of titanium dental implants is possible, but it depends heavily on the geometric shape of the implant, anodization parameters, and environment composition. The parameters proposed here make it possible to obtain the nanotubes on the bottom of the helix and distinctly roughen almost all remaining surfaces. However, the applied conditions applied indicate that future investigations be oriented towards oxidation of the whole surface by introducing slightly higher HF contents and lower current values and mixing the electrolyte bath.

Author Contributions: Conceptualization, M.J.; methodology, M.J. and M.B.; formal analysis, M.J. and M.B.; investigation, M.J. and M.B.; writing—original draft preparation, M.J.; writing—review and editing, M.J. and M.B.; supervision, M.J. All authors have read and agreed to the published version of the manuscript.

Funding: This research received no external funding.

Institutional Review Board Statement: Not applicable.

Informed Consent Statement: Not applicable.

Data Availability Statement: The data presented in this study are available on request from the corresponding author.

Acknowledgments: Authors thank the students-M. Get, M. Karczmarczyk, and K. Gasiorowska for their technical assistance in some tests. The helpful comments of Andrzej Zielinski are gratefully acknowledged.

Conflicts of Interest: The authors declare no conflict of interest. 


\section{References}

1. Osman, R.B.; Swain, M.V. A critical review of dental implant materials with an emphasis on titanium versus zirconia. Materials 2015, 8, 932-958. [CrossRef] [PubMed]

2. Le Guéhennec, L.; Soueidan, A.; Layrolle, P.; Amouriq, Y. Surface treatments of titanium dental implants for rapid osseointegration. Dent. Mater. 2007, 23, 844-854. [CrossRef] [PubMed]

3. Mendoza-Arnau, A.; Vallecillo-Capilla, M.F.; Cabrerizo-Vílchez, M.Á.; Rosales-Leal, J.I. Topographic characterisation of dental implants for commercial use. Med. Oral Patol. Oral Cir. Bucal 2016, 21, e631-e636. [CrossRef] [PubMed]

4. Kulkarni, M.; Mazare, A.; Schmuki, P.; Iglič, A. Biomaterial Surface Modification Of Titanium and Titanium Alloys for Medical Applications. In Nanomedicine; One Central Press: Altrincham, UK, 2014; pp. 111-136.

5. Ellingsen, J.E.; Johansson, C.B.; Wennerberg, A.; Holmen, A. Improved retention and bone-tolmplant contact with fluoridemodified titanium implants. Int. J. Oral Maxillofac. Implant. 2004, 19, 659-666.

6. Buser, D.; Broggini, N.; Wieland, M.; Schenk, R.K.; Denzer, A.J.; Cochran, D.L.; Hoffmann, B.; Lussi, A.; Steinemann, S.G. Enhanced bone apposition to a chemically modified SLA titanium surface. J. Dent. Res. 2004, 83, 529-533. [CrossRef] [PubMed]

7. Garg, H.; Bedi, G.; Garg, A. Implant surface modifications: A review. J. Clin. Diagn. Res. 2012, 6, 319-324.

8. Gehrke, S.A.; Taschieri, S.; Massimo, D.P.; Coelho, P.G. The positive biomechanical effects of titanium oxide for sandblasting implant surface as an alternative to aluminium oxide. J. Oral Implantol. 2015, 41, 515-522. [CrossRef]

9. Majkowska-Marzec, B.; Tęczar, P.; Bartmański, M.; Bartosewicz, B.; Jankiewicz, B.J. Mechanical and Corrosion Properties of Laser Surface-Treated Ti13Nb13Zr Alloy with MWCNTs Coatings. Materials 2020, 13, 3991. [CrossRef]

10. Pawłowski, Ł.; Bartmański, M.; Strugała, G.; Mielewczyk-Gryń, A.; Jażdżewska, M.; Zieliński, A. Electrophoretic Deposition and Characterization of Chitosan/Eudragit E 100 Coatings on Titanium Substrate. Coatings 2020, 10, 607. [CrossRef]

11. Puckett, S.D.; Taylor, E.; Raimondo, T.; Webster, T.J. The relationship between the nanostructure of titanium surfaces and bacterial attachment. Biomaterials 2010, 31, 706-713. [CrossRef]

12. Scopelliti, P.E.; Borgonovo, A.; Indrieri, M.; Giorgetti, L.; Bongiorno, G.; Carbone, R.; Podestà, A.; Milani, P. The effect of surface nanometre-scale morphology on protein adsorption. PLoS ONE 2010, 5, e11862. [CrossRef] [PubMed]

13. Zinger, O.; Anselme, K.; Denzer, A.; Habersetzer, P.; Wieland, M.; Jeanfils, J.; Hardouin, P.; Landolt, D. Time-dependent morphology and adhesion of osteoblastic cells on titanium model surfaces featuring scale-resolved topography. Biomaterials 2004, 25, 2695-2711. [CrossRef] [PubMed]

14. Kohavi, D.; Badihi Hauslich, L.; Rosen, G.; Steinberg, D.; Sela, M.N. Wettability versus electrostatic forces in fibronectin and albumin adsorption to titanium surfaces. Clin. Oral Implant. Res. 2013, 24, 1002-1008. [CrossRef] [PubMed]

15. Brett, P.M.; Harle, J.; Salih, V.; Mihoc, R.; Olsen, I.; Jones, F.H.; Tonetti, M. Roughness response genes in osteoblasts. Bone 2004, 35, 124-133. [CrossRef] [PubMed]

16. Webster, T.J.; Ejiofor, J.U. Increased osteoblast adhesion on nanophase metals: Ti, Ti6Al4V, and CoCrMo. Biomaterials 2004, 25, 4731-4739. [CrossRef] [PubMed]

17. Gittens, R.A.; Olivares-Navarrete, R.; Schwartz, Z.; Boyan, B.D. Implant osseointegration and the role of microroughness and nanostructures: Lessons for spine implants. Acta Biomater. 2014, 10, 3363-3371. [CrossRef]

18. Pinheiro, F.A.L.; de Almeida Barros Mourão, C.F.; Diniz, V.S.; Silva, P.C.; Meirelles, L.; Junior, E.S.; Schanaider, A. In-vivo bone response to titanium screw implants anodized in sodium sulfate1. Acta Cir. Bras. 2014, 29, 376-382. [CrossRef]

19. Ogawa, T.; Saruwatari, L.; Takeuchi, K.; Aita, H.; Ohno, N. Ti nano-nodular structuring for bone integration and regeneration. J. Dent. Res. 2008, 87, 751-756. [CrossRef]

20. Sugita, Y.; Ishizaki, K.; Iwasa, F.; Ueno, T.; Minamikawa, H.; Yamada, M.; Suzuki, T.; Ogawa, T. Effects of pico-to-nanometer-thin $\mathrm{TiO} 2$ coating on the biological properties of microroughened titanium. Biomaterials 2011, 32, 8374-8384. [CrossRef]

21. Liu, X.; Chu, P.K.; Ding, C. Surface modification of titanium, titanium alloys, and related materials for biomedical applications. Mater. Sci. Eng. R Rep. 2004, 47, 49-121. [CrossRef]

22. Tailor, S.; Rakoch, A.G.; Gladkova, A.A.; Van Truong, P.; Strekalina, D.M.; Sourkouni, G.; Manjunath, S.Y.; Takagi, T. Kinetic features of wear-resistant coating growth by plasma electrolytic oxidation. Surf. Innov. 2018, 6, 150-158. [CrossRef]

23. Aydogan, D.T.; Muhaffel, F.; Acar, O.K.; Topcuoglu, E.N.; Kulekci, H.G.; Kose, G.T.; Baydogan, M.; Cimenoglu, H. Surface modification of Ti6Al4V by micro-arc oxidation in AgC2H3O2-containing electrolyte. Surf. Innov. 2018, 6, 277-285. [CrossRef]

24. Webster, T.J.; Yao, C. Anodization: A Promising Nano-Modification Technique of Titanium-based Implants for Orthopedic Appl. In Surface Engineered Surgical Tools and Medical Devices; Jackson, M.J., Ahmed, W., Eds.; Springer US: Boston, MA, USA, 2007; pp. 21-47.

25. Li, G.; Qu, S.; Ren, Z.; Li, X. Surface Modification Layer of Ti-6Al-4V Produced By Surface Rolling and Thermal Oxidation. Surf. Innov. 2017, 5, 1-29. [CrossRef]

26. Sul, Y.T. The significance of the surface properties of oxidized titanium to the bone response: Special emphasis on potential biochemical bonding of oxidized titanium implant. Biomaterials 2003, 24, 3893-3907. [CrossRef]

27. Sul, Y.T.; Johansson, C.B.; Jeong, Y.; Wennerberg, A.; Albrektsson, T. Resonance frequency and removal torque analysis of implants with turned and anodized surface oxides. Clin. Oral Implant. Res. 2002, 13, 252-259. [CrossRef] [PubMed]

28. Sul, Y.T.; Johansson, C.B.; Petronis, S.; Krozer, A.; Jeong, Y.; Wennerberg, A.; Albrektsson, T. Characteristics of the surface oxides on turned and electrochemically oxidized pure titanium implants up to dielectric breakdown: The oxide thickness, micropore configurations, surface roughness, crystal structure and chemical composition. Biomaterials 2002, 23, 491-501. [CrossRef] 
29. Sul, Y.-T.; Johansson, C.B.; Albrektsson, T. Oxidized titanium screws coated with calcium ions and their performance in rabbit bone. Int. J. Oral Maxillofac. Implant. 2002, 17, 625-634.

30. Choi, J.W.; Heo, S.J.; Koak, J.Y.; Kim, S.K.; Lim, Y.J.; Kim, S.H.; Lee, J.B. Biological responses of anodized titanium implants under different current voltages. J. Oral Rehabil. 2006, 33, 889-897. [CrossRef]

31. Elias, C.N. Titanium dental implant surfaces. Rev. Mater. 2010, 15, 138-142. [CrossRef]

32. Shayganpour, A.; Rebaudi, A.; Cortella, P.; Diaspro, A.; Salerno, M. Electrochemical coating of dental implants with anodic porous titania for enhanced osteointegration. Beilstein J. Nanotechnol. 2015, 6, 2183-2192. [CrossRef]

33. Van Vuuren, D.J.; Laubscher, R.F. Surface Friction Behaviour of Anodized Commercially Pure Titanium Screw Assemblies. Procedia CIRP 2016, 45, 251-254. [CrossRef]

34. Nasir, M.; Abdul Rahman, H. Mechanical Evaluation of Pure Titanium Dental Implants Coated with a Mixture of Nano Titanium Oxide and Nano Hydroxyapatite. J. Baghdad Coll. Dent. 2016, 28, 38-43. [CrossRef]

35. Portan, D.V.; Nikolopoulou, F.; Bairami, V.; Mouzakis, D.; Papanicolaou, G.C.; Deligianni, D.D. Electrochemical Surface Processing Applied for the Functionalization of Titanium Screw Type Implants. J. Mater. Sci. Surf. Eng. 2016, 4, 376-382.

36. Huang, J.; Zhang, X.; Yan, W.; Chen, Z.; Shuai, X.; Wang, A.; Wang, Y. Nanotubular topography enhances the bioactivity of titanium implants. Nanomed. Nanotechnol. Biol. Med. 2017, 13, 1913-1923. [CrossRef]

37. Oliveira, W.F.; Arruda, I.R.S.; Silva, G.M.M.; Machado, G.; Coelho, L.C.B.B.; Correia, M.T.S. Functionalization of titanium dioxide nanotubes with biomolecules for biomedical applications. Mater. Sci. Eng. C 2017, 81, 597-606. [CrossRef]

38. Weszl, M.; Tóth, K.L.; Kientzl, I.; Nagy, P.; Pammer, D.; Pelyhe, L.; Vrana, N.E.; Scharnweber, D.; Wolf-Brandstetter, C.; Joób, F.Á.; et al. Investigation of the mechanical and chemical characteristics of nanotubular and nano-pitted anodic films on grade 2 titanium dental implant materials. Mater. Sci. Eng. C 2017, 78, 69-78. [CrossRef]

39. Suchanek, K.; Hajdyła, M.; Maximenko, A.; Zarzycki, A.; Marszałek, M.; Jany, B.R.; Krok, F. The influence of nanoporous anodic titanium oxide substrates on the growth of the crystalline hydroxyapatite coatings. Mater. Chem. Phys. 2017, 186, 167-178. [CrossRef]

40. Yazici, H.; Habib, G.; Boone, K.; Urgen, M.; Utku, F.S.; Tamerler, C. Self-assembling antimicrobial peptides on nanotubular titanium surfaces coated with calcium phosphate for local therapy. Mater. Sci. Eng. C 2019, 94, 333-343. [CrossRef]

41. Wang, L.-N.; Jin, M.; Zheng, Y.; Guan, Y.; Lu, X.; Luo, J.-L. Surface modification of metallic implants with anodic oxide nanotubular arrays via electrochemical anodization techniques. In Nanomedicine; Seifalian, A., de Mel, A., Kalaskar, D.M., Eds.; One Central Press Ltd.: Manchester, UK, 2015; pp. 313-332.

42. Ossowska, A.; Sobieszczyk, S.; Supernak, M.; Zielinski, A. Morphology and properties of nanotubular oxide layer on the "Ti-13Zr-13Nb" alloy. Surf. Coat. Technol. 2014, 258, 1239-1248. [CrossRef]

43. Ossowska, A.; Beutner, R.; Scharnweber, D.; Zielinski, A. Properties of composite oxide layers on the Ti13Nb13Zr alloy. Surf. Eng. 2017, 33, 841-848. [CrossRef]

44. EN ISO 10993-15:2009. Biological Evaluation of Medical Devices. Identification and Quantification of Degradation Products from Metals and Alloys; ISO: Geneva, Switzerland, 2009.

45. Ehlert, M.; Radtke, A.; Jędrzejewski, T.; Roszek, K.; Bartmański, M.; Piszczek, P. In Vitro Studies on Nanoporous, Nanotubular and Nanosponge-Like Titania Coatings, with the Use of Adipose-Derived Stem Cells. Materials 2020, 13, 1574. [CrossRef]

46. Alam, F.; Balani, K. Adhesion force of staphylococcus aureus on various biomaterial surfaces. J. Mech. Behav. Biomed. Mater. 2017, 65, 872-880. [CrossRef]

47. Macak, J.M.; Schmuki, P. Anodic growth of self-organized anodic $\mathrm{TiO}_{2}$ nanotubes in viscous electrolytes. Electrochim. Acta 2006, 52, 1258-1264. [CrossRef]

48. Klimas, J.; Dudek, A.; Klimas, M. Surface Refinement of Titanium Alloy TI6AL4V ELI. Eng. Biomater. 2012, 15, 52-54.

49. Bartmanski, M.; Zielinski, A.; Majkowska-Marzec, B.; Strugala, G. Effects of solution composition and electrophoretic deposition voltage on various properties of nanohydroxyapatite coatings on the Ti13Zr13Nb alloy. Ceram. Int. 2018, 44, 19236-19246. [CrossRef] 